\title{
Allelic Sharing Among Madurese as a Tool of Madurese Identification Using 11 Short Tandem Repeats and Amelogenin Gene: An Observational Analytical Study
}

\author{
Ahmad Yudianto ${ }^{1,2}$, Agung Sosiawann ${ }^{1,3}$, Abdul Hadi Furqoni' ${ }^{1}$, Indah Nuraini Masjkur ${ }^{1}$, Qurrota A'yunil Huda \\ ${ }^{1}$ Human Genetic and Forensic Laboratory, Institute of Tropical Disease, ${ }^{2}$ Department of Forensic Medicine, Faculty of Medicine, ${ }^{3}$ Department of Dental Public Health, \\ Faculty of Dental Medicine, Universitas Airlangga, Surabaya, Indonesia
}

\section{Abstract}

Aim: To analyze the allelic sharing and a set of preferable short tandem repeats (STRs) loci among the Madurese full siblings. Materials and Methods: This was an observational analytical study. The research subjects were determined from 20 Madurese families that originated from Madura Island, Indonesia consisting of father, mother, and two biological children. The blood samples were collected, and kinship relationship was examined by using the PCR-STR technique by 11 loci of genotyped STR alleles and a sextyping amelogenin locus. Calculations of combined sibship indices (CSIs) for each pair were done to determine the likelihood ratios. Results: Based on 220 observations (20 pairs of full sibling x 11 loci) of the STR allele genotype, 4 STR loci were found: D8S1179, F13, CSF1PO, and FES. A high-shared allelic frequency was found in two alleles that were shared among 11 STR loci by 57 times $(25.9 \%)$, one allele shared among eleven STR loci by 130 times (59.1\%), and zero alleles by 33 times (15.0\%). Conclusion: This study indicated the power of one allele in the sibship among a Madurese establishment through the 11 STR loci.

Keywords: Allele, Full Sibling, Madurese, STR Loci

Received: 07-05-2020, Revised: 10-08-2020, Accepted: 12-08-2020, Published: 28-01-2021.

\section{INTRODUCTION}

The STRs are widespread throughout the human genome and the richest source of polymorphic markers that can be recognized by a polymerase chain reaction (PCR) ${ }^{[1]}$ The STRs contain repeat units that are two to six base pairs in length, and a common tool in forensic analysis because they only need low amounts of DNA, even in a degraded form. ${ }^{[2,3]}$ The STRs are classified as a modern technology of DNA typing that has the ability to carry out the human identity test. Even though the establishment of the STR is a rigorous process, the purpose of identification by using STR is very useful to determine the perpetrator of violent crimes (murder and sexual assault). ${ }^{[4]}$ Moreover, the identification by using STR can be used for various purposes, including sibship full-sibling determination. ${ }^{[5]}$ Genomic variation occurs between geographical boundaries, individual locus, and STR accuracy

\begin{tabular}{|l|l|}
\hline \multicolumn{2}{|c|}{ Access this article online } \\
\hline Quick Response Code: & Website: \\
& www.jioh.org \\
\cline { 2 - 2 } & \\
\hline
\end{tabular}

establishment based on population. The inclusive STR determination in a nation helps in the establishment of a database, a reference point, and a notable set of the STR core that can effectively determine the population. ${ }^{[6]}$ Sibship relationship can also be used to prevent the incest or incest sexual intercouse between family members. Incest can include the relationship between real or adoptive father and child, siblings, grandfather and grandchildren, uncles and nieces, and between all of the family members. Most of all, girls are the victims in such conditions. ${ }^{[7,8]}$

\section{Address for correspondence: Dr. Agung Sosiawan Department of Dental Public Health, Faculty of Dental Medicine, Human Genetic and Forensic Laboratory, Institute of Tropical Disease, Universitas Airlangga, Surabaya 60286, Indonesia. E-mail: agung-s@fkg.unair.ac.id}

This is an open access journal, and articles are distributed under the terms of the Creative Commons Attribution-NonCommercial-ShareAlike 4.0 License, which allows others to remix, tweak, and build upon the work non-commercially, as long as appropriate credit is given and the new creations are licensed under the identical terms. For reprints contact: reprints@medknow.com

How to cite this article: Yudianto A, Sosiawan A, Furqoni AH, Masjkur IN, Huda QA. Allelic sharing among madurese as a tool of madurese identification using 11 short tandem repeats and amelogenin gene: An observational analytical study. J Int Oral Health 2021;13:89-92. 
There are 28 STR systems, namely D3S1358, TH01, D21S11, D18S51, Penta E, D5S818, D13S317, D7S820, D16S539, CSF1PO, Penta D, vWA, D8S1179, TPOX, FGA， D19S433， D2S1338， D22S1045, D1S1656, D10S1248, D2S441, D12S391, SE33, LPL, F13B, FESFPS, F13A01, and Penta C and 20.000 STR loci, that can be used and amplified by PCR. The STR loci are chosen based on the local dedicated project, because it can overlap with the other STR loci and the worldwide shared locus inclusivity. The variability of identity repeated in the unit of length in both allele and STR matching among people offers the frequency of likelihood disparity among the population in different territories. The characteristics of one population related to the other population suggest a localized population that is based on the STR derivative, even though it can be marginalized in the number of overlapping nations. ${ }^{[5,6,9]}$

The application of the amelogenin gene in forensic case works is using two types, such as amelogenin X-linked (AMELX) and amelogenin Y-linked (AMELY). The location of AMELX is on the distal part of the short arm of chromosome X p22.1-p22.3 region, and AMELY is near the centromer of the $Y$ chromosome $\mathrm{p} 11.2$. AMELX and AMELY products can be distinguished by PCR that uses a primer flanking a $6 \mathrm{bp}$ deletion in the third intron of AMELX. In AMELY, the deletion is not present. ${ }^{[10]}$ The study aimed at establishing the allelic sharing and a set of preferable STR loci among the Madurese full sibling.

\section{Materials and Methods}

\section{Setting and design}

This observational analytical study was conducted from September to December 2019 at Human Genetic Laboratory, Institute of Tropical Disease, Universitas Airlangga, Indonesia. The sample size was 20 full-sibling individuals. Inclusion criteria consisted of full siblings of Madurese origin from Madura Island, Indonesia, which included alleged father, mother, and their biological two children who were nonidentical twins and agreed to participate in the study. In each of the cases, neither the alleged mother nor the alleged father was included as biological parents of either child, nor were mutational events detected. The parental alleles were ignored after case selection, as if the parents were unavailable.

\section{Study method}

The blood from the peripheral blood system was extracted for DNA extraction. DNA extraction in this study used DNAzol Organic (Invitrogen, USA) method protocol. ${ }^{[11,12]}$
After extracting the DNA concentration, purity was measured by using an ultraviolet spectrophotometer (Shimidzu UV-16, Kyoto, Japan). ${ }^{[11,12]}$ Amplification of DNA was carried out by PCR-STR (PowerPlex ${ }^{\circledR}$ 21 Systems, Promega, USA) using 11 STRs combined DNA index (CODIS) systems with the Federal Bureau of Investigation standard and the amelogenin gene for determination of gender (GoTaq ${ }^{\circledR}$ Green Master Mix, Promega Corp., Madison, USA). The locusization of PCR-STR products was electrophoresed by using $6 \%$ poliacrylamide gel (Life Science Group, UK). The results of the visualization were then analyzed to determine the full-sibling pattern in the kinship analysis. ${ }^{[13]}$

\section{STR loci analysis}

The known siblings by the logic and calculations for the full-sibling index/sibship index (SI) were calculated based on the kinship analysis equations. ${ }^{[13]}$ The allele probabilities were taken from allele frequencies among the Indonesian population. The descriptions of shared alleles were presented together with the likelihood ratios favoring sibship. Finally, the calculation of CSIs for each pair was done to determine the likelihood ratios. The CSIs were determined by multiplying the individual SI values of the chosen loci. ${ }^{[14]}$

\section{RESULTS}

The allele-sharing degree in the present and previous published study is presented in Table 1 . Among the 220 observations $(20$ pairs $\times 11$ loci $)$ in true siblings, two alleles per locus were shared 57 times $(25.9 \%)$, one allele was shared 130 times $(59.1 \%)$, and zero alleles were shared 33 times $(15.0 \%)$.

The percentage of evidence strength found in this study is presented in Table 2. Overall, 100\% of 20 true sibling pairs had likelihood ratios favoring sibship (i.e., their CSI values were greater than 1). The CSI ranges are from 1.4 to higher than 37 billion in the 20 known full-sibling pairs. All of the notable sibling pairs had CSIs greater than 10 , and the majority of them $(65 \%)$ had CSIs higher than 1000 .

\section{Discussion}

The areas that contain repeated sequences of nucleotides such as STR sequences are of interest for forensic sciences, because they have a lot of information about the variation that makes them useful for human identification purposes.

The good indicators that are based on the allelic frequencies are homozygosity, heterozygosity, an

Table 1: The probability of allele-sharing degree in sibling pairs

\begin{tabular}{lccc}
\hline Study & Zero allele & One allele & Two alleles \\
\hline Current study & $15.0 \%$ & $59.1 \%$ & $25.9 \%$ \\
Wenk, 1996 & $18.3 \%$ & $53.4 \%$ & $28.3 \%$ \\
\hline
\end{tabular}


Yudianto, et al.: Allelic sharing among Madurese using 11 short tandem repeats and amelogenin gene

\begin{tabular}{|c|c|c|}
\hline \multicolumn{3}{|c|}{$\begin{array}{l}\text { Table 2: The percentage of evidence strength found in this } \\
\text { study }\end{array}$} \\
\hline CSIs & Evidence strength & Percentage in this study \\
\hline $1-33$ & Weak & 15 \\
\hline $33-100$ & Fair & 10 \\
\hline $100-330$ & Good & 0 \\
\hline $330-1000$ & Strong & 10 \\
\hline$>1000$ & Very strong & 65 \\
\hline
\end{tabular}

effective number of alleles, the content of polymorphism information, the discrimination power, and the exclusion power. A good indicator of genetic polymorphisms is based on the number of alleles. This can be caused by the presence of unique alleles in populations. Therefore, genetic screening must be done before conducting the research. It is theorized that a bigger population size will increase the number of observed alleles. ${ }^{[15]}$

Full siblings are intended to share zero or two identical alleles by descent at a certain locus with an equal probability of 0.25 and also share a single allele with a probability of $0.5 .^{[16]}$ In the current study, full siblings shared $15 \%, 60 \%$, and $26 \%$ zero, single, and two identical alleles, respectively. The allele-sharing degree in the current study was comparable to that of other studies. ${ }^{[16]}$ This variation was probably caused by the ethnicity that has contributed to different genetics between the populations. It can be linked to the historical demographic processes, which lead to genetic drift.

The fact that $75 \%$ and $65 \%$ of the sibling pairs had CSIs higher than 100 and 1000 (strong and very strong evidences), respectively, indicates that the current STR system is very promising to identify siblings of Madurese. This was strengthened by the United States of Citizenship and Immigration Services (USCIS) report, where it was found that only $9 \%$ of samples were excluded from the fullsibling relationships in tests using 20 loci. The report also shows that sibling kinship analysis is one of the personal identifications that needs to be considered, because until now there have been no standard locus for the STR examination for the purposes of full-sibling kinship analysis. The standard locus that can be used for the STR examination must have a $90 \%$ or more probability level. ${ }^{[17]}$

One thing that needs to be consider in the analysis of sibling kinship is the possibility of coomon allele in certain focus areas of STRs. The locus of STRs that have a tendency to have these coomon alleles should be aware before they are withdrawn as a conclusion in personal identification. ${ }^{[18]}$ Furthermore, the family originating from marriage consanguity increases the complexity of full sibling analysis by the increased of co-ancetry. Therefore caution is needed in the process of interpreting the results of the full-sibling STR examination. ${ }^{[19]}$

The results of this study can be either high or low: If the results are low, alternative choices can be got by two options. The first option is that the research must use another locus that is still related to the chosen locus. The second option is that the research can use additional DNA testing from the respective uncles, aunts, and cousins. ${ }^{[20]}$ This is because shared alleles cannot be found in full-sibling kinship analysis. ${ }^{[6]}$ More importantly, the use of 20 STRs examination locations in personal identification, based on full-sibling kinship analysis, becomes an unavoidable requirement to reach the $90 \%$ probability standard as determined by the USCIS. ${ }^{[18]}$ It aims at increasing the power of discrimination for forensic DNA examination. ${ }^{[21]}$

This study is important as a basis for the personal identification process based on sibling kinship analysis using 11 STRs and the amelogenin gene, when the analysis of the parental inheritance of children is not possible. This study also has implications for oral health. This study can be used as a basis for whether a person has a tendency to have genetic disorders, especially in the oral cavity when she/he has the same or a close percentage of a locus pattern with STR determination. This study could be a predictor of similarity in siblings against certain genetic diseases, especially in the oral cavity such as the cleft palate. Microsatellites are markers that are commonly used in genetic analysis, as in the case of the cleft palate. This is related to the nature of these markers that have high mutation rates or, in other words, have a high polymorphism. The STR is one type of microsatellite marker that has a high polymorphism, so it is used for genetic forensic analysis. Indeed, there has been no genetic analysis in dentistry such as cleft palate using STR, but that does not mean it is not possible to be used in genetic analysis for cleft palate. So far, the cleft palate used five microsatellite markers such as DLX3, MSX1, RARA, BCL3, and EDN1. ${ }^{[22,23]}$

\section{Conclusion}

From the overview of the guidance for the sibling DNA test, it can be concluded that the one allele is the strongest one compared with the two and zero alleles. The mark of one allele is $59.1 \%$ and this indicates that full-sibling interpretation supports the fact that the claimed relationship exists. The difficulties experienced in the low number of DNA samples that have been obtained can be overcome by using another locus that is related to the chosen locus or additional DNA that is obtained from uncles, aunts, and cousins. In future, genetic analysis using STRs will be very useful in the dental field, especially for cleft palate study analysis.

\section{Acknowledgment}

We thank Rector Universitas Airlangga for financial support of this study.

Financial support and sponsorship

This research was funded by the Riset Mandat Grant (No 622/UN3.14/LT/2018). 
Yudianto, et al:: Allelic sharing among Madurese using 11 short tandem repeats and amelogenin gene

\section{Conflicts of interest}

There are no conflicts of interest.

\section{Author contributions}

Ahmad Yudianto: study design, data collection and article writing; Agung Sosiawan: study design, data acquisition and analysis, and article writing; Abdul Hadi Furqoni: data collection, data interpretation; Indah Nuraini Masjkur: data collection, statistical analysis; and Qurrota A'yunil Huda: data collection. All authors approved the final version of the article for publication.

\section{Ethical policy and institutional review board statement}

This study was carried out under ethical committee clearance approval issued by Health Research Ethical Committee Faculty of Dental Medicine, Universitas Airlangga, Indonesia (524/HRECC.FODM/VII/2019).

\section{Patient declaration of consent}

Not applicable.

\section{Data availability statement}

Not applicable.

\section{RefEREnCES}

1. Goodwin E, Linacre A, Hadi S. An Introduction to Forensic Genetics. 2nd ed. Chichester, UK: John Wiley \& Sons Ltd; 2007. p. 21-31.

2. Ruitberg CM, Reeder DJ, Butler JM. Strbase: A short tandem repeat DNA database for the human identity testing community. Nucleic Acids Res 2001;29:320-2.

3. Fotsing SF, Margoliash J, Wang C, Saini S, Yanicky R, ShleizerBurko $\mathrm{S}$, et al. The impact of short tandem repeat variation on gene expression. Nat Genet 2019;51:1652-9.

4. El-Alfy SH, El-Hafez AF. Paternity testing and forensic DNA typing by multiplex STR analysis using ABI PRISM 310 genetic analyzer. J Genet Eng Biotechnol 2012;10:101-12.

5. Abbas S, Mourad L, Mansour I. Evaluation of sibling-ship analysis in secluded Lebanese vilages with increased mating patterns. J Forensic Investig 2018;6:1-4.

6. Sosiawan A, Yudianto A, Furqoni AH, Nzilibili SMM, Nuraini I. Full-sibling allelic frequency and sharing among Madurese: STR technique by 12 locus and the sex-typing amelogenin gene. Egypt $\mathbf{J}$ Forensic Sci 2019;9(Suppl 38):1-10.

7. Consentino E, Turrina S, Ferrian M, Caratti S, De Leo D. Sibling incest. Forensic Sci Int Genetics 2015;5:e472-3.
8. Karbeyaz K, Toygar M, Celikel A. Case of sibling incest resulting in pregnancy. Egypt J Forensic Sci 2016;6:550-2.

9. Yamamoto T, Mizutani M, Uchihi R, Tanaka M, Yoshimoto T, Misawa S, et al. Allele distributions and genetic relationship with 13 CODIS core STR loci in various Asian populations in or near Japan. Inter Con Series 2003;1239:117-20.

10. Butler E, Li R. Genetic markers for sex identification in forensic DNA analysis. J Forensic Investig 2014;2:1-1.

11. Chen H, Rangasamy M, Tan SY, Wang H, Siegfried BD. Evaluation of five methods for total DNA extraction from western corn rootworm beetles. PLoS One 2010;5:1-6. doi: 10.1371/journal. pone. 0011963

12. McClintock JT. Forensic Analysis of Biological Evidence: A Laboratory Guide for Serological and DNA Typing. 2014. https://books.google com/books?id=4HLNBQAAQBAJ\&pgis=1. [Last accessed on 2020 Mar 03].

13. Slooten K. Validation of DNA-based identification software by computation of pedigree likelihood ratios. Forensic Sci Int Genetics 2011;5:308-15.

14. Tzeng CH, Lyou JY, Chen YR, Hu HY, Lin JS, Wang SY, et al. Determination of sibship by PCR-amplified short tandem repeat analysis in Taiwan. Transfusion 2000;40:840-5.

15. Bull L. Genetics, Mutations, and Polymorphisms. In: Madame Curie Bioscience Database [Internet]. Austin (TX): Landes Bioscience; 2000-2013. Available from: https://www.ncbi.nlm.nih.gov/books/ NBK6475/ [Last accessed on 2020 Mar 11].

16. Wenk RE, Traveer M, Chiafari M. Determination of sibship in any two persons. Transfusion 1996;36:259-62.

17. U.S. Citizenship and Immigration Services Office of the Director 2018. DNA evidence of sibling relationships April 17, 2018 policy memorandum. PM-602-0106.1. Available from: https://www.uscis gov/sites/default/files/document/memos/2018-04-17-PM-DNAEvidence-of-Sibling-Relationships.pdf. [Last accessed on 2020 Feb 12].

18. Paoletti DR, Doom TE, Krane CM, Raymer ML, Krane DE. Empirical analysis of the STR profiles resulting from conceptual mixtures. J Forensic Sci 2005;50:1361-6.

19. Sharma AK, High TG. Autosomal STR allele sharing between full siblings Australian. J Forensic Sci 2010;42:137-40.

20. Yang IS, Lee HY, Park SJ, Yang WI, Shi KJ. Analysis of kinship index distributions in Koreans using simulated autosomal STR profiles. Korean J Legal Med 2013;37:57-65.

21. Hares DR. Selection and implementation of expanded CODIS core loci in the United States. Forensic Sci Int Genetics 2015;17:33-4.

22. Blanco R, Suazo J, Santos JL, Paredes M, Sung H, Carreño H, et al. Association between 10 microsatellite markers and nonsyndromic cleft lip palate in the Chilean population. Cleft Palate Craniofac J 2004;41:163-7.

23. Xavier D, Arif Y, Murali R, Kishore Kumar S, Vipin Kumar S, Tamang R, et al. Analysis of microsatellite polymorphisms in South Indian patients with non syndromic cleft lip and palate. Balkan J Med Genetics 2013;16:49-54 